\title{
Correspondence
}

\section{Genetics of human behaviour}

Sir: It is a pity that Dr Moncrieff (Psychiatric Bulletin. March 1998, 22, 158-161) has misunderstood the scientific evidence underpinning the role of genetic factors in influencing human behaviour, and that she is moved to rehearse arguments regarding reductionism and positivism that owe more to gut feeling than logical analysis. Behaviour genetics may be materialist but it is not necessarily reductionist or deterministic. Most of its proponents are not seeking to replace the languages of psychology and sociology with those of genetics or even physics. What we are seeking to demonstrate is that propensity to certain mental states or behaviours is associated with particular genes or combinations of genes. By doing this we hope to be able to understand better the neurobiology of mental disorders to allow better therapies to be developed. Nor can we be accused of genetic determinism. Indeed behaviour genetics emphasises the complexity of gene-environment co-actions and interactions in normal and abnormal human behaviour (Rutter \& Plomin, 1997), and we and our colleagues have stressed the need to develop research strategies combining the best of genetic, psychological and social approaches (Owen \& McGuffin, 1997).

Dr Moncrieffs article is littered with errors and misconceptions. For example, she muddles heritability with the monozygotic twin concordance rate. She is surprised that high heritability can be compatible with a majority of people with schizophrenia having no family history of the disorder, and she fails to grasp the concept of allelic association in a polygenic disorder.

She has also misrepresented our article in the British Journal of Psychiatry (Farmer \& Owen, 1996). She asserts that we have applauded "Huxlean visions of a technology of behavioural manipulation using drugs to correct for the consequence of having the wrong sort of genes". We have said nothing of the sort. Rather we have suggested that the aetiological clues provided by an increased understanding of the role of genetic factors in disorders such as schizophrenia and depression may lead to the development of safer more specific drug therapies; hardly an evil aim.

Not content with that, Dr Moncrieff goes further and states that we have advocated "the use of drugs to correct undesirable behaviours arising from putative genetic abnormalities" and that this is based "on the same rationale" as a proposal made in the 1970 s to use psychosurgery to manage the disruptive behaviour of innercity militants. Extraordinary stuff, but we suppose that it reflects an exercise of free will to stretch iconoclastic argument to the very boundaries of defamation rather than having anything to do with her genes.

FARMER, A. \& OWEN, M. (1996) Genomics: the next psychiatric revolution? British Journal of Psychiatry. 169. 135-138.

OWEN, M. J. \& MCGUFFin, P. (1997) Genetics and psychiatry. British Journal of Psychiatry, 171, 201-202.

RUTTER, M. \& PLOMIN, R. (1997) Opportunities for psychiatry from genetic findings. British Journal of Psychiatry. 171, 209-219.

ANNE FARMER, Michael OWEN and PETER MCGUFFIN, University of Wales College of Medicine, Division of Psychological Medicine, Heath Park, Cardiff CF4 4XN

Author's reply: I am sorry if any personal offence was caused by my article on behaviour genetics (Psychiatric Bulletin, March 1998, 22, 158-161), as this was no part of my intention. Although I do not question the motives of those involved in research in this area, I do not share their confidence, and the tacit consensus of much of psychiatry, that this work will evidently produce beneficial results. I am merely trying to indicate how evidence is generally presented in a way which emphasises the significance of a genetic component to causation. Selective emphasis is not unique to genetics, but the point I wish to make is that the role of genetics in psychiatric disorders may be taken for granted in a way that is not entirely warranted. I am well aware that modern geneticists talk in terms of propensities, but this does not alter my basic argument. The question is, propensities for what? There is no objective or neutral way of defining voluntary human activity. The meaning given to an action depends on the understanding of the person describing it. Looking for genetic contributions to behavioural propensities is like looking for the explanation of good manners or good music. What is designated as such varies between different people with different points of view at different times.

Whether psychiatric disorders consist of voluntary patterns of behaviour is another area of debate which I have chosen to avoid. Most people would agree that the patterns of behaviour associated with Alzheimer's disease and 